\title{
LEGAL REGULATION OF PUBLIC PROPERTY IN THE CONDITIONS OF ECONOMIC TRANSFORMATION
}

\author{
Miroslava Sirant ${ }^{1}$, Olena Paruta ${ }^{2}$, Iryna Andrusyak ${ }^{3}$
}

\begin{abstract}
The purpose of the article is to characterize the legal regulation of relations in the field of public ownership, which is an important economic resource for the fulfilment of tasks and functions assigned to the state. Approaches to understanding public ownership as an economic and social category are analysed, its relationship with property in the general sense is clarified. It is stated that public property is one of the most important categories in our lives because we use it every day, regardless of our desire. At the same time, the level of vital activity and improvement of the population in each state depends, first of all, on how much it provides its citizens with the property of the commons, that is, that property which every person can use, regardless of status, age, sex, religion or any other characteristics. Special attention is paid to the features of legal regulation of public property relations in the conditions of the transformation of the economy. General and special features of public property are identified. Some features of the formation of concepts concerning the understanding of public property in foreign countries and the experience of legal regulation of public property relations are revealed. It is proved that the existing legal acts on control over public property necessitate us to conclude on the unsatisfactory state of legal regulation in this sphere. The main directions for solving this problem are: transfer of legal regulation to the legislative level, as well as the systematization and partial abolition of departmental acts; clear definition of control objects; establishment of a system of control subjects and principles for the division of competences between them; differentiated consolidation of content and control procedures depending on the type of public property, legal regime of its use, and other factors (control over the legality, the efficiency of the property use, its preservation, etc.). Practical importance of scientific results of the study is the clarification of concepts of "public ownership", "public property" in the context of legal regulation, which is important for the successful socio-economic development of the state and promotes the identification of those factors hampering the development of the economy, the development and further improvement of the legal framework, which regulates the economy and affects the development of an effective economic crisis exit strategy. The public property of the state is not only one of the most important elements in ensuring the fulfilment of state functions but also the basic, decisive condition for the observance and realization of national interests. In view of this, scientific research in this area is relevant and timely in the period of the search for the priorities of the state economic policy. Methodology. The methodological basis of the study of public ownership is determined a set of methods of scientific knowledge that allow considering this problem as a multidimensional, interdisciplinary phenomenon. On the basis of system-structural, system-functional, and other scientific approaches, the concept of public ownership as a complex system category, covering the theoretical and practical level of economic activity of the state, has developed.
\end{abstract}

Key words: property, state property, communal property, legal regulation, economic resource, objects of public property.

\section{JEL Classification: G32, Q15, J54}

\section{Introduction}

In the current conditions of development of the Ukrainian state, when the cardinal reconstruction of all spheres of society's life, in particular economic, the state's maximum desire to achieve the relevant international standards and entry into the European Union became a key point, the issue of improving the legal regulation of relations in the field of public property becomes of paramount importance.

\footnotetext{
Corresponding author:

${ }^{1}$ Lviv Polytechnic National University, Ukraine.

E-mail: myroslava55m@gmail.com

${ }^{2}$ Lviv Polytechnic National University, Ukraine.

E-mail: parutaolena@ukr.net

${ }^{3}$ Lviv Polytechnic National University, Ukraine.

E-mail: aip2604@ukr.net
} 
It should be noted that relations in the field of property as a whole are undoubtedly the economic fundamentals of any state and society, regardless of how they are formed and developed. As the well-known law theorist S. Alekseev rightly notes, “The modern stage of society's development, especially its liberal, post-industrial stage when the opportunities and positive qualities of civil society are fully disclosed, requires from certain objects of property, regardless of its form, to be recognized as public" (Alekseev, 2010).

Instead, it must be noted that the formation of the institution of public property rights is still far from its completion, given that in scientific works of economic and legal direction, this issue is still the subject of fierce debate.

\section{Public property concepts of the continental legal system}

As V. Ustymenko and R. Dzhabrailov rightly point, defining general and special features of public property as a subject of scientific research, "the transformations that took place in the global economy during the $\mathrm{XX}$ and the beginning of the XXI century, determined the vector of development of property relations. In most countries of the world, there was a revision of the legal fundamentals of the organization of property relations with the provision of important means of ensuring the balance of public and private interests of owners. In addition, it was followed by a new assessment of the existing scientific conclusions obtained earlier based on the consideration of system interconnections of property relations in the conditions of the dominance of the theory of market fundamentalism. New scientific approaches allowed drawing a conclusion on the appearance of previously unexplored or not studied perfectly aspects of the development of property relations in the context of the formation of initial provisions on the priority of values of a mixed socially oriented economy" (Ustymenko, Dzhabrailov, 2012).

Instead, it should be noted that many countries in the sphere of public property, first of all, those included in the continental legal system, have taken Roman law tradition as the basis, as evidenced by terminology, classification of property, etc. However, there are also some distinctions, which can be traced on the example of some countries such as France and Germany.

Thus, in France, which is reasonably considered to be a country of classical administrative law, there is a division of property owned by the state and other persons of public law into public property (domaine public) regulated by special rules of public law, as well as private property (domaine prive) regulated by civil law. It is believed that first preconditions for distinguishing public property in this state were made in the period of the French Revolution while its first clearly enough appearance was in 1804 along with the adoption of the French civil code (Godfrin, 2001). However, scientific sources indicate that the theoretical substantiation of the concept of distribution of property in France was laid by J.-M. Pardessus (Pardessus, 1838) whose scientific views were supported by E.-V. Foucart (Foucart, 1834). In more details, J.-B.-V. Proudhon enshrined the issue of public ownership in his famous work "A Treatise on Public Domain" (Proudhon, 2010).

Starting from the middle of the XX century, not only in the doctrine but also in the judicial practice, the approach began to dominate, according to which public domains are a special type of property, which: 1) is either intended for use directly by the public; 2 ) or used by the public service on the condition that the relevant facilities are adapted for this due to their natural properties or as a result of special equipment for the needs of the relevant service (Aub, Bon, Auby, 2003).

Therefore, modern public property doctrine of France is based on another fundamental category - the category of public services (service public), which today is one of the system-making categories in the administrative law of this state. Nevertheless, the convergence of public and private property should also be recognized as one of the features of the modern period, which results in a certain evolution of the property management system, aimed at its valorisation, that is, an economic assessment and an increase in profits, in particular: 1) concessions and other tools for investing in public ownership objects are actively used based on the public-private partnership; 2) competition law was extended to the sphere of private property relations; 3 ) the pan-European principle of transparency is implemented in the provision of public property to private persons, which is a means of forming the common market (Aub, Bon, Auby, 2003).

The concept of public property that has been formed in France has significantly influenced the legal systems of other states, including Ukraine.

But it should be noted that the division of property into objects of public and private property is adopted not in all states of the continental legal system. First of all, it is absent in German law, where an alternative doctrine of "modified private property" (Theorie vom modifizierten Privateigentum) has been formed for the public property (offentlichen Sachen). In scientific sources, such a doctrine is also called the "dualistic" concept of a property right as opposed to the "monistic" concept of France.

\section{Public property relations as the subject- matter of administrative property law}

It is worth noting that in the science of administrative law, public property relations are investigated mainly from more narrow positions - within the framework of issues of management of state and communal property (Vynnytskyi, 2005). These traditions were established during the Soviet period, and some contemporary authors adhere to them.

It is obvious that today, the sphere of administrative legal regulation of state and communal property relations should be approached somewhat broadly, more beyond the issues 
of property management. Therefore, an administrative legal concept not just proposes changing a narrow approach to the institution of state property management. Administrative property law covers all groups of relations and processes associated with the property provision by the public administration to perform state functions and functions of local self-government bodies, in particular:

- planning for the public property;

- formation of warehouses of public domain, necessary and sufficient for the performance of functions of state or local self-government;

- management of the formed warehouses of public property by organizing and ensuring its use within the performance of state or local self-government functions; - accounting and control of the public property.

Most scholars believe that the subject-matter of legal regulation - the main criterion for the organization of legal matter. Such a relatively separate subject of regulation is manifested in the administrative property law since relations regarding the provision of property by the public administration for state and local self-government functions have a certain specificity and, by their material object, they are always more noticeable from among other relations in the field of administrative law. To regulate these relations, the regulatory framework, consisting of many laws and regulations, a significant number of by-laws, is objectively formed and continues to actively develop.

Relations governed by administrative property law are heterogeneous. Their classification can be carried out on different grounds:

firstly, based on the content of relations, within which the planning, formation of warehouses of public property, their management, as well as accounting and control, are carried out;

secondly, by the intended purpose of the property: relations concerning public domain objects; objects providing the provision of public services, other activities in the public interest; property for the satisfaction of individual economic needs, etc.;

thirdly, depending on the natural properties of public domain objects: relations concerning the movable property, property complexes, infrastructural facilities of the real estate, land plots, forest areas, water objects, other natural resources, etc.;

fourthly, based on the subject of ownership: relations with the state, regional property and property of local self-government bodies.

At the same time, relations governed by administrative and property law have a number of common features:

1) are formed in relation to property that is in the public domain or comes to it;

2) public administration body is an obligatory participant in relations;

3) their content - the powers of administrative bodies in respect of property that is in the public domain or acquired in public ownership, as well as the corresponding rights and obligations of other persons;
4) the exercise of powers by administrative authorities becomes law-enforcement and acquires proceduralprocessual form;

5) are regulated by the general-sector method, subordinated to the general-sector mode. As a result, the relations under consideration can be characterized as organizational and property.

\section{Control over public property}

Control over the public property - an administrativeprocedural activity that, like accounting, aims to get the corresponding result, is organizational, and has secondary (accompanying) character, providing proper public administration and use of state and communal property.

Control is the most important type of feedback, in which the authorities receive information about the actual state of affairs, the execution of the decisions made (Stetsenko, 2008).

According to scholars, it is necessary to talk about state property control, which is carried out by state authorities (both legislative and executive); its object is the activities of organizations on the use of state property; control assessment of such activity is carried out on the basis of the principles and purposes of the use of state property, as well as the goals and objectives of its management (Bortnyk, Yesimov, 2015).

Therefore, public administration and the use of state and communal property should be considered as the object of control. When analysing the subjects of control in this area, it is first necessary to distinguish between the administrative and legal control activities of public administration bodies and other control activities. The latter include:

1) control of legislative authorities on the activities of public administration regarding the public property;

2) presidential control over the activities of the public administration on public property;

3) control by the accountancy chamber, other similar bodies over the public administration activities regarding the public property, as well as over the use of this property by other persons;

4) public prosecutor's supervision of the public administration activities regarding the public property, as well as over its use within the limits and in cases established by law.

\section{Conclusions}

Analysis of the existing legal acts on control over public property necessitates us to conclude on the not quite satisfactory state of legal regulation in this sphere. First and foremost, it should be improved in the following areas:

1) transfer of legal regulation to the legislative level, as well as the systematization and partial abolition of departmental acts; 
2) clear definition of control objects;

3) establishment of a system of control subjects and principles for the division of competences between them;
4) differentiated consolidation of content and control procedures depending on the type of public property, legal regime of its use, and other factors (control over the legality, the efficiency of the property use, its preservation, etc.).

\section{References:}

Alekseev, S. S. (2010). Property rights. Theory problems. 3rd edition, revised and expanded. Moskva: Norma: Infra-M, $240 \mathrm{p}$.

Ustymenko, V.A. (2014). Public property: problems of theory and practice: monograph. NAS of Ukraine, Institute of Economic and Legal Research. Chernihiv: Desna Polihraf, 308 p.

Mamutov, V. K. (Sc. Ed.) at al. (2012). The role of public property in ensuring the socio-economic development of Ukraine: materials of the Intern. Scientific-Practical Conf., 18 September 2012, Donetsk; NAS of Ukraine, Institute of Economic and Legal Research. Donetsk: Yugo-Vostok, 224 p.

Kremenovska, I. (2012). The future of public ownership. Law Herald of Ukraine. 6-12 Oct. (№ 40), 3-6.

Kremenovska, I. V. The role of public property in ensuring the socio-economic development of Ukraine. URL: http://www.aprnu.kharkiv.org/news_18092012.html; http://iepd.dn.ua; http://www.hozpravo.com.ua/ news/index.php?ELEMENT ID=645

Ustymenko, V., Dzhabrailov, $\bar{R}$. (2012). General and special features of public ownership as a subject of scientific research. Civil law problems, 4(71), 185-200.

Godfrin, Ph. (2001). Droit administrative des biens. $6^{e}$ ëd. P.: Dalloz, 3-7.

Pardessus, J.-M. Traitë des servitudes ou services fonciers. $8^{\mathrm{e}}$ ëd. P.: Nëve, 1838.

Foucart, E.-V. Elëments de droit public et administrative ou Exposë mëthodique du droit public positif. 3 vol. $1^{\mathrm{e}}$ ëd. P.: Videcoq, 1834-1835.

Proudhon, J.-B.-V. (2010). Traite du domaine public, ou de la Distinction des biens consideres principalement par rapport au domaine public. Vol. 1 (French edition). Nabu Press (BiblioBazaar / BiblioLife).

Auby, J.-M., Bon, P., Auby, J.-B. (2003). Droit administrative des biens. 4e ed. P.: Dalloz, 9, 96-98.

Vynnytskyi, A. V.(2005). The administrative and legal framework of state property management: thesis for Cand. Sc. (Jurisprudence). Ekaterinburg, $283 \mathrm{p}$.

Stetsenko, S. H. (2008). Administrative law of Ukraine: study guide. Kyiv: Atika, 624 p.

Bortnyk, N. P., Yesimov, S. S. (2015). Principles of financial control in the system of investment and legal policy. Herald of Lviv Polytechnic National University. Series: Legal Sciences, 824, 14-21. 